\title{
PREDIKSI PENGGUNAAN BANDWIDTH MENGGUNAKAN ELMAN RECURRENT NEURAL NETWORK
}

\author{
Jefri Radjabaycolle ${ }^{1}$, Reza Pulungan ${ }^{2}$ \\ ${ }^{1,2}$ Jurusan Ilmu Komputer dan Elektronika, FMIPA UGM, Yogyakarta \\ e-mail: ${ }^{1}$ jefriradja@gmail.com, ${ }^{2}$ pulungan@ugm.ac.id
}

\begin{abstract}
Abstrak
Jaringan Syaraf Tiruan (JST) sering dipakai dalam menyelesaikan permasalahan tertentu seperti prediksi, klasifikasi, dan pengolahan data. Berdasarkan hal tersebut, dalam penelitian ini mencoba menerapkan JST untuk menangani permasalahan dalam prediksi penggunaan bandwidth. Sistem yang dikembangkan dapat digunakan untuk memprediksi pengunaan bandwidth dengan menerapkan Elman Recurrent Neural Network (ERNN). Struktur Elman dipilih karena dapat membuat iterasi jauh lebih cepat sehingga memudahkan proses konvergensi.. Vektor input yang digunakan menggunakan windows size. Hasil penelitian dengan menggunakan target error sebesar 0.001 menunjukkan nilai MSE terkecil yaitu pada windows size 11 dengan nilai 0.002833 . Kemudian dengan menggunakan 13 neuron pada hidden layer diperoleh nilai error paling optimal (minimum error) sebesar 0.003725 .
\end{abstract}

Kata kunci : Prediksi, Bandwidth, jaringan syaraf tiruan (JST), elman recurrent neural network

\section{PREDICTIONS OF BANDWIDTH USING ELMAN RECURRENT NEURAL NETWORK}

\begin{abstract}
Artificial Neural Network (ANN) can be used to solve specific problems such as prediction, classification, and data processing. Accordingly, in this study tries to apply neural networks to deal with the problem of prediction bandwidth usage. The system developed can be used to predict the bandwidth usage by applying Elman Recurrent Neural Network (ERNN). Elman structure chosen because it can make much faster iterations so as to facilitate the process of convergence. Input vector used to use windows size. The results using a target error of 0001 showed the smallest MSE value is on the windows size 11 with a value of 0.002833 . Then, using 13 neurons in the hidden Layer error values obtained most optimal (minimum error) amounted to 0.003725 .
\end{abstract}

Keywords : Prediction, Bandwidth, artificial neural network (ANN), elman recurrent neural network

\section{Pendahuluan}

Bandwidth merupakan ukuran jumlah data yang dapat melakukan perjalanan lebih dari satu sistem komunikasi yang dialokasikan dalam rentang waktu atau disebut juga sebagai kecepatan data. Bandwidth juga memiliki arti bahwa semakin besar bandwidth bisa menghasilkan komunikasi yang lebih cepat. Ketersediaan bandwidth jaringan merupakan faktor penting dalam memilih layanan web. Pada dasarnya besarnya kebutuhan bandwidth mempresentasikan kapasitas dari koneksi, semakin tinggi kebutuhan bandwidth, umumnya akan diikuti oleh kinerja yang lebih baik. Salah satu solusi yang paling efektif untuk mengatasinya adalah dengan mengelola pemakaian bandwidth yang menghasilkan suatu kualitas layanan lalu lintas aliran data yang baik dan berkualitas.

Kemampuan untuk mengantisipasi kebutuhan bandwidth sangat penting untuk layanan yang efisien dan pengambilan keputusan cerdas dalam menghadapi perkembangan lalu lintas yang cepat dan perubahan pola lalu lintas [1]. Pada dasarnya besarnya kebutuhan bandwidth mempresentasikan kapasitas dari koneksi, semakin tinggi kebutuhan bandwidth, umumnya akan diikuti oleh kinerja yang lebih baik, meskipun kinerja keseluruhan juga tergantung pada faktor-faktor lain, misalnya latency yaitu waktu tunda antara masa sebuah 
perangkat meminta akses ke jaringan dan masa perangkat itu memberi izin untuk melakukan transmisi .

Khususnya yang terjadi di lingkungan kampus Universitas Pattimura, terdapat beberapa keluhan dari pengguna jaringan internet. Mahasiswa maupun karyawan dan dosen di Universitas Pattimura mengeluhkan adanya koneksi internet yang dirasa kurang sesuai dengan apa yang diharapkan, misalnya dari segi kecepatan ataupun kestabilan koneksi. Kecepatan koneksi yang didapatkan oleh pengguna tidak hanya dipengaruhi oleh alokasi bandwidth yang diberikan oleh pihak kampus tetapi dipengaruhi juga oleh alokasi bandwidth yang disediakan oleh penyedia layanan server yang diakses atau dituju oleh pengguna. Dari pihak administrator jaringan di Universitas Pattimura, diperoleh informasi total bandwidth yang dimiliki pihak kampus dengan pembagian alokasi bandwidth berdasarkan jumlah pengguna pada setiap departemen atau bagian yang ada. Secara garis besar ada beberapa faktor yang harus dipertimbangkan dalam menentukan alokasi bandwidth yaitu jumlah departemen beserta karyawan yang ada dalam setiap departemen, jumlah dosen, jumlah mahasiswa, serta alokasi khusus yang diperlukan untuk layanan server untuk mendukung kegiatan belajar mengajar di kampus. Permasalahan yang muncul dari pembagian bandwidth yang sudah dilaksanakan adalah sudah tepatkah pembagian bandwidth yang diimplementasikan untuk saat ini, perlu dilakukan perubahan atau tidak untuk pembagian bandwidth nya sehingga biaya yang dikeluarkan untuk sewa bandwidth dapat menjadi efektif dan efisien.

Berangkat dari permasalahan yang sudah disebutkan diatas, diperlukan adanya analisa lebih mendalam mengenai berapa kebutuhan bandwidth yang harus disediakan oleh pihak kampus sehingga layanan koneksi internet maupun Local Area Network (LAN) dapat berjalan dan mendukung semua aktifitas yang memerlukan kondisi network dengan layanan yang sesuai. Untuk membantu pihak manajemen menentukan alokasi yang tepat untuk sewa bandwidth maka dibutuhkan suatu sistem yang dapat memprediksi penggunaan bandwidth menggunakan jaringan syaraf tiruan dengan algoritma Elman Recurrent Neural Network. Struktur Elman dipilih karena dapat membuat iterasi jauh lebih cepat dan konvergensi akan menjadi lebih cepat yang disebabkan oleh jaringan Elman memiliki feedback yang menawarkan proses pembelajaran yang lebih cepat pada jaringan [2]. Kemampuan belajar yang dimilikinya dapat dilatih untuk mempelajari dan menganalisa pola data masa lalu dan berusaha mencari suatu formula atau fungsi yang akan menghubungkan pola data masa lalu dengan keluaran yang diinginkan pada saat ini [3].

\section{Metode Penelitian}

\subsection{Arsitektur ERRN (Elman Recurrent Neural Network)}

Recurrent Neural Network adalah salah satu bagian dari model artificial neural network yang mempunyai feedback dari keluaran hidden Layer ke masukan input Layer . Recurrent Neural Network mempunyai struktur dan algoritma pelatihan yang lebih kompleks dibandingkan feed-forward neural network. Pada Recurrent Neural Network, output dari network digunakan kembali sebagai input network. Elman Recurrent Neural disebut partial recurrent neural network karena recurrent weight adalah tetap [4]. Network ditambahkan di layer context sebagai tambahan layer proses. Biasanya network ini merupakan feedfroward neural network. Pelatihan dilakukan pada hubungan forward. Sedangkan hubungan backward dari output Layer ke input Layer tidak dapat dilakukan pelatihan. Layer context digunakan untuk mengingat status terakhir dari hidden layer. Output dari network tergantung dari status sebelum maupun status network pada saat ini. Kemampuan dalam mengingat status terakhir menjadikan network ini memiliki memori yang dinamis. Arsitektur Elman Neural Network hampir sama dengan arsitektur feedforward backpropagation, namun ditambah dengan layer context untuk menampung hasil output dari hidden layer . Layer akan di update tidak hanya pada input jaringan saja tapi juga dengan aktivasi forward propagation sebelumnya.

Elman Recurrent Neural Network merupakan variasi dari Multi Layer Perceptron. Akan tetapi pada Elman Recurrent Neural Network terdapat beberapa node yang posisinya berdekatan dengan input layer yang berhubungan dengan hidden layer. Node-node tersebut mengandung isi dari salah satu layer yang telah dilatih sebelumnya. Pada prinsipnya, masukan disebarkan secara feed forward yang kemudian diberikan suatu learning rule. Jaringan jenis dapat memelihara suatu urutan keadaan dan mengijinkannya untuk melakukan beberapa pekerjaan sekaligus, contohnya seperti sequence prediction yang berada diluar kemampuan Multi Layer Perceptron [4]. Masukan tidak hanya nilai dari luar jaringan, tetapi ditambah dengan nilai keluaran dari neuron tersembunyi dari propagasi sebelumnya. Gambar 1 merupakan struktur Elman Recurrent Network. 


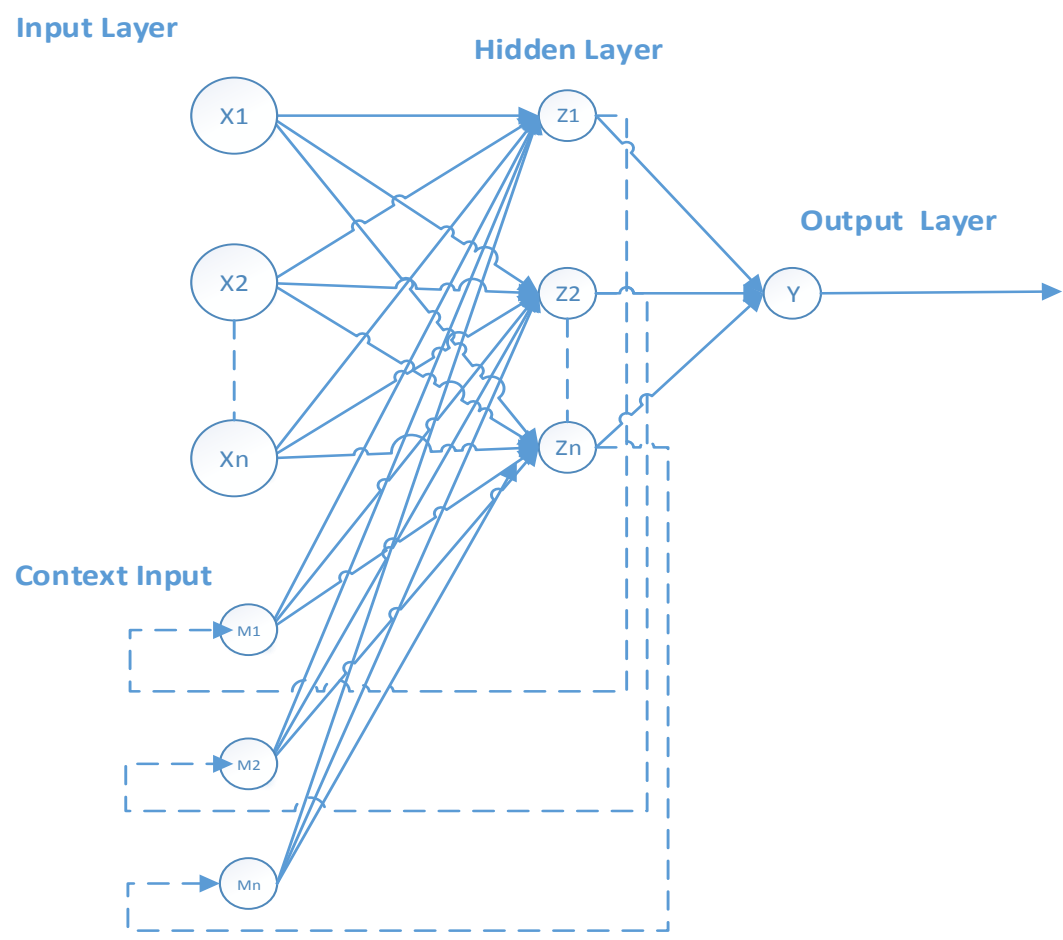

Gambar 1. Arsitektur Elman Recurrent Neural Network

Model jaringan syaraf tiruan untuk prediksi pemakaian dan penggunaan bandwidth menggunakan struktur jaringan syaraf tiruan 3 layer /lapisan. Struktur jaringan syaraf tiruan 3 layer terdiri dari sebuah layer input, sebuah layer hidden, sebuah layer output dan context input.

\subsection{Algoritma Elman Recurrent Neural Network}

Jaringan Elman vector input akan dipropagasikan melalui layer bobot dan akan dikombinasikan dengan aktifasi sebelumnya memlaui layer bobot recurrent tambahan yaitu $\mathrm{U}$ seperti pada Gambar 2 dimana $\mathrm{U}$ adalah bobot delay.

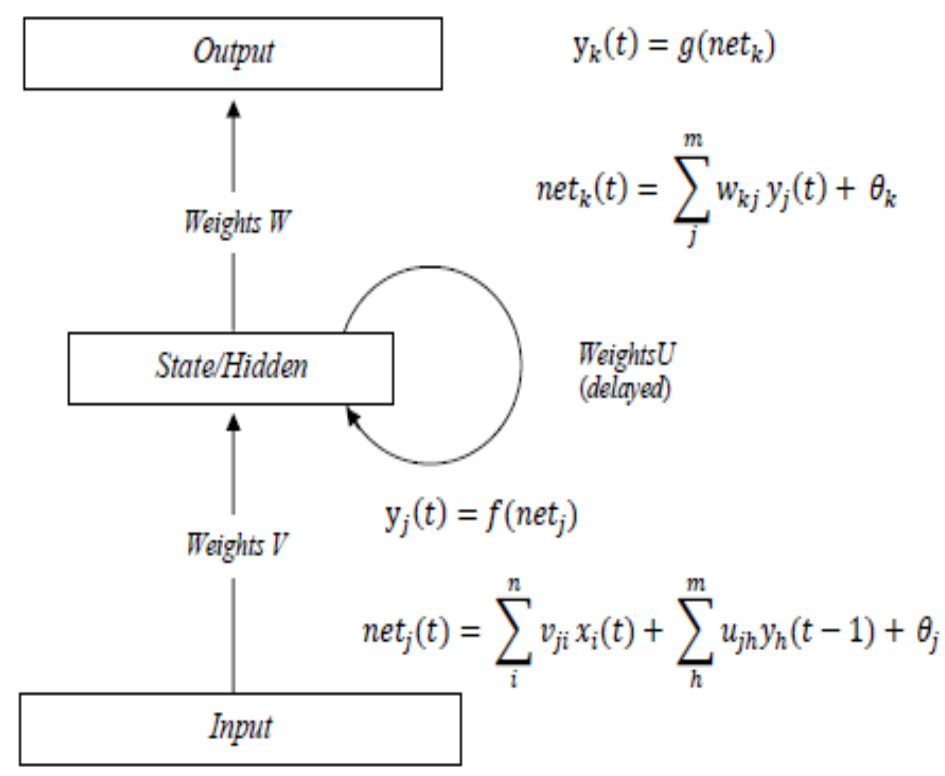

\section{Gambar 2. Jaringan Elman}

Setiap kali sebuah pattern disajikan, unit akan menghitung aktifasinya seperti halnya pada jaringan feedforward. Adapun tahapan dalam algoritma JST Recurrent Elman adalah sebagai berikut : 
Tahap 1 : Training pola input atau vector saat time $(t)$ seperti persamaan (1)

$$
y_{t}(t)=f\left(\text { net }_{j}\right)
$$

dengan jaringan recurrent seperti pada persamaan (2)

$$
\operatorname{net}_{j}(t)=\sum_{i}^{n} v_{j i} x_{i}(t)+\sum_{h}^{m} u_{j h} y_{h}(t-1)+\theta_{j}
$$

Tahap 2 : Output jaringan ditentukan oleh lapisan context dan satu set output berbobot $(w)$ seperti persamaan (3), yang kemudian dapat dijabarkan menjadi persamaan (4).

$$
\begin{array}{r}
y_{k}(t)=g\left(\operatorname{net}_{k}(t)\right) \\
\operatorname{net}_{k}(t)=\sum_{j}^{m} w_{k j} y_{j}(t) \theta_{k}
\end{array}
$$

Tahap 3 : Back propagation untuk jaringan recurrent, Setiap bobot dimodifikasi, dimana fungsi biaya (kesalahan) sehubungan dengan bobot dihitung dan kemudian disesuaikan. Fungsi biaya yang digunakan dalam penelitian ini adalah Mean Square Error (MSE) pada persamaan (5)

$$
M S E=\frac{1}{n} \sum_{p}^{n} \sum_{k}^{m}\left(d_{p k}-y_{p k}\right)^{2}
$$

keterangan :

$d$ : ouput yang diinginkan

$n \quad$ : jumlah total sampel

$m$ : jumlah node output

Tahap 4 : Menurut gradient descent, setiap perubahan bobot dalam jaringan harus sebanding dengan gradient negatif dari biaya sehubungan dengan tertentu yang tertarik untuk dimodifikasi. $\eta$ adalah sebuah learning rate seperti pada persamaan (6).

$$
\Delta w=-\eta \frac{\partial C}{\partial w}
$$

Tahap 5 :Menggunakan aturan rantai dari diferensiasi, bobot berkaitan dengan error pada output dapat dinyatakan dengan persamaan (7).

$$
\delta_{p k}=-\frac{\partial C}{\partial y_{p k}} \frac{\partial y_{p k}}{\partial n e t_{p k}}=\left(d_{p k}-y_{p k}\right) g^{\prime}\left(y_{p k}\right)
$$

Sedangkan error pada hidden layer dinyatakan dengan persamaan (8)

$$
\delta_{p j}=-\left(\sum_{k}^{m} \frac{\partial C}{\partial y_{p k}} \frac{\partial y_{p k}}{\partial n e t_{p k}} \frac{\partial n e t_{p k}}{y_{p j}}\right) \frac{\partial y_{p j}}{\partial n e t_{p j}}=\sum_{k=1}^{m} \delta_{p k} w_{k j} f^{\prime}\left(y_{p j}\right)
$$

Dimana $m$ adalah neuron pada lapisan output. 
Tahap 6 : Perubahan bobot untuk output dinyatakan dengan persamaan (9). Sedangkan

persamaan (10) untuk perubahan bobot input.

$$
\begin{array}{r}
\Delta w_{k j}=\eta \sum_{p}^{n} \delta_{p k} y_{p j} \\
\Delta v_{j i}=\eta \sum_{p}^{n} \delta_{p j} y_{p i}
\end{array}
$$

Tahap 7 : Berdasarkan komponen waktu, perubahan bobot recurrent dapat dinyatakan seperti persamaan (11).

$$
\Delta u_{j h}=\eta \sum_{p}^{n} \delta_{p j}(t) y_{p h}(t-1)
$$

Tahap 8 : Pelatihan akan berhenti apabila error $<$ target error.

\section{3 Teori Prediksi}

Secara umum pengertian prediksi adalah tafsiran. Namun dengan menggunakan teknik-teknik tertentu maka prediksi bukan hanya sekedar tafsiran. Ada beberapa definisi tentang prediksi, diantaranya :

1. Prediksi diartikan sebagai penggunaan teknik-teknik statistik dalam bentuk gambaran masa depan berdasarkan pengolahan angka angka historis.

2. Prediksi merupakan bagian integral dari kegiatan pengambilan keputusan manajemen.

3. Prediksi adalah peramalan, rencana, atau estimasi kejadian masa depan yang tidak pasti. Selain itu prediksi juga dapat diartikan sebagai penggunaan teknik-teknik statistik dalam membentuk gambaran masa depan berdasarkan pengolahan angka-angka historis.

Metode prediksi merupakan cara memperkirakan apa yang akan terjadi pada masa depan secara sistematis dan pragmatis atas dasar data yang relevan pada masa yang lalu, sehingga dengan demikian metode prediksi diharapkan dapat memberikan objektivitas yang lebih besar. Selain itu metode prediksi dapat memberikan cara pengerjaan yang teratur dan terarah, dengan demikian dapat dimungkinkannya penggunaan teknik penganalisaan yang lebih maju. Dengan penggunaan teknik-teknik tersebut maka diharapkan dapat memberikan tingkat kepercayaan dan keyakinan yang lebih besar, karena dapat diuji penyimpangan atau deviasi yang terjadi secara ilmiah.

\section{3.1 Jenis Prediksi}

Berdasarkan sifatnya, prediksi dibedakan atas dua macam yaitu :

a. Prediksi kualitatif adalah prediksi yang didasarkan atas pendapat suatu pihak, dan datanya tidak bisa direpresentasikan secara tegas menjadi suatu angka atau nilai. Hasil prediksi yang dibuat sangat bergantung pada orang yang menyusunnya. Hal ini penting karena hasil prediksi tersebut ditentukan berdasarkan pemikiran yang instuisi, pendapat dan pengetahuan serta pengalaman penyusunnya.

b. Prediksi kuantitatif adalah prediksi yang didasarkan atas data kuantitatif masa lalu (data historis) dan dapat dibuat dalam bentuk angka yang biasa disebut sebagai data time series

Hasil prediksi yang dibuat sangat bergantung pada metode yang dipergunakan dalam prediksi tersebut. Baik tidaknya metode yang dipergunakan ditentukan oleh perbedaan atau penyimpangan antara hasil ramalan dengan kenyataan yang terjadi. Semakin penyimpangan antara hasil ramalan dengan kenyataan yang akan terjadi maka semakin baik pula metode yang digunakan. 


\subsubsection{Pengukuran Prediksi}

Teknik prediksi tidak selamanya selalu tepat karena teknik prediksi yang digunakan belum tentu sesuai dengan sifat datanya, atau disebabkan oleh kondisi di luar bisnis yang mengharuskan bisnis itu menyesuaikan diri. Oleh karena itu, perlu diadakan pengawasan prediksi sehingga dapat diketahui sesuai atau tidaknya teknik prediksi yang digunakan. Sehingga dapat dipilih dan ditentukan teknik prediksi yang lebih sesuai dengan cara menentukan batas toleransi prediksi atas penyimpangan yang terjadi.

Pada prinsipnya, pengawasan prediksi dilakukan dengan membandingkan hasil prediksi dengan kenyataan yang terjadi. Penggunaan teknik prediksi yang menghasilkan penyimpangan terkecil adalah teknik prediksi yang paling sesuai untuk digunakan.

Besarnya error prediksi dihitung dengan mengurangi data riil dengan besarnya ramalan pada persamaan (12).

$$
\operatorname{Error}(E)=X t \quad F t
$$

$$
\begin{aligned}
& \text { Keterangan } \\
& \mathrm{X}_{t}=\text { Data riil periode ke- } t \\
& \mathrm{~F}_{t}=\text { Ramalan Periode ke- } t
\end{aligned}
$$

\section{4 Proses Jaringan Syaraf Tiruan}

Penerapan jaringan syaraf tiruan dalam permasalahan prediksi penggunaan bandwidth meliputi penentuan komponen-komponen jaringan syaraf tiruan yang digunakan dengan langkah-langkah sebagai berikut [5] :

1. Menentukan variabel masukan.

2. Jumlah masukan ditentukan berdasarkan data jumlah penggunaan bandwidth di Universitas Pattimura.

3. Menentukan jumlah neuron pada hidden layer dan context layer .

4. Banyaknya jumlah neuron yang digunakan pada hiden layer dan context layer akan menentukan kinerja sistem ketika memprediksi penggunaan bandwidth. Hal ini disebabkan karena semakin banyak neuron dalam hidden layer dan context layer maka akan membuat neuron tersebut memiliki beban yang semakin sedikit dalam menampung data-data yang harus dipelajari. Hidden layer dan context layer ditentukan secara trial dan error sampai didapatkan hasil yang terbaik.

5. Menentukan parameter pembelajaran, yaitu maksimum epoch, toleransi error dan learning rate.

6. Menentukan fungsi bobot yang akan digunakan berdasarkan fungsi aktivasi. Penentuan nilai bobot minimum dan maksimum ditentukan atas dasar $0<n<1$ yang merupakan jangkauan dari fungsi. Fungsi ini digunakan untuk jaringan syaraf tiruan yang dilatih dengan menggunakan metode Elman Recurrent. Fungsi sigmoid biner mempunyai nilai antara 0 sampai 1. Fungsi ini sering digunakan jaringan syaraf tiruan yang membutuhkan nilai output yang terletak pada interval 0 sampai 1.

7. Menentukan output.

Nilai output ditentukan berdasarkan hasil yang diinginkan yaitu nilai berkisar antara 0 sampai 1 yang merepresentasikan nilai prediksi bandwidth, yang selanjutnya didenormalisasikan supaya menjadi nilai prediksi aktual.

\section{Hasil dan Pembahasan}

\subsection{Analisis Preprosessing Data}

Preprosessing data bertujuan untuk memilih data yang digunakan sebagai data penelitian, namun sebelumnya data tersebut di normalisasi terlebih dahulu. Dimana hasil normalisasi data tersebut selanjutnya di representasikan kedalam sliding windows dengan windows size sebesar lima. Proses sliding windows mengakibatkan data penelitian di reduksi karena proses penentuan data awal menjadi berubah. Total data 
penelitian menjadi 82 vektor data, pada Tabel 1 menunjukan contoh penerapan windows size pada data penelitian.

Tabel 1. Data penelitian dengan windows size 5

\begin{tabular}{|c|c|c|l|l|l|}
\hline \multicolumn{1}{|c|}{$\mathbf{x 1} \mathbf{1}^{\prime}$} & \multicolumn{1}{c|}{$\mathbf{x 2}^{\prime}$} & \multicolumn{1}{c|}{$\mathbf{x 3}^{\prime}$} & \multicolumn{1}{|c|}{$\mathbf{x 4}^{\prime}$} & \multicolumn{1}{c|}{$\mathbf{x 5}^{\prime}$} & \multicolumn{1}{c|}{$\mathbf{y}^{\prime}$} \\
\hline 0.313 & 0.246267 & 0.291533 & 0.245333 & 0.207067 & 0.2968 \\
\hline 0.246267 & 0.291533 & 0.245333 & 0.207067 & 0.2968 & 0.252533 \\
\hline 0.291533 & 0.245333 & 0.207067 & 0.2968 & 0.252533 & 0.142733 \\
\hline 0.245333 & 0.207067 & 0.2968 & 0.252533 & 0.142733 & 0.3354 \\
\hline 0.207067 & 0.2968 & 0.252533 & 0.142733 & 0.3354 & 0.2636 \\
\hline$\ldots$ & $\ldots$ & $\ldots$ & $\ldots$ & & $\ldots$ \\
\hline
\end{tabular}

Data penelitian dengan sliding windows 5 selanjutnya dikelompokkan menjadi dua kelompok, yaitu data training sebanyak $80 \%$ dari keseluruhan data dan data testing sebanyak 20\% dari data penelitian. Dari data keseluruhan yang berjumlah 82 vektor data maka didapatkan data yang menjadi data training set adalah sejumlah 67 data dan data yang menjadi data testing set sejumlah 15 data.

\subsection{Training dengan nilai window size}

Percobaan pertama untuk mendapatkan nilai windows size yang tepat yang menjadi parameter pengujian agar didapatkan hasil yang memiliki tingkat akurasi yang tinggi. Terdapat beberapa percobaan yang dilakukan, dan hasil yang dijadikan sebagai acuan awal adalah jumlah epoch maksimal yaitu 100.000 dan 1.000.000. Pelatihan akan berhenti jika telah mendapatkan MSE < target errror atau telah mencapai maksimum epoch yang ditentukan. Parameter training untuk pengujian nilai windows size dapat dilihat pada Tabel 2.

Tabel 2. Parameter training nilai windows size dengan epoch 100.000

\begin{tabular}{|l|c|l|}
\hline \multicolumn{1}{|c|}{ Parameter } & Nilai & \multicolumn{1}{c|}{ Keterangan } \\
\hline Target error (MSE) & 0,001 & Target proses berhenti \\
\hline Learning rate & 0,1 & Kecepatan pembelajaran sistem \\
\hline Jumlah Hidden & 3 & Jumlah lapisan tersembunyi \\
\hline Maksimum epoch & 100.000 & Jumlah iterasi \\
\hline Transfer Function & Sigmoid Binner \\
\hline Bobot & Random $(0,1)$ \\
\end{tabular}

Hasil training dari percobaan ini adalah nilai dari windows size yang digunakan untuk mencari nilai MSE terkecil dengan epoch proses yang telah ditentukan. Nilai MSE terkecil yang didapatkan adalah 0.003277 dengan jumlah epoch sebanyak 100.000 epoch, hasil ini didapatkan pada nilai input/windows size delapan.

\subsection{Training dengan jumlah neuron pada hidden layer}

Jumlah neuron sangat mempengaruhi pada keakuratan hasil prediksi terhadap data yang digunakan dalam jaringan Elman Recurrent Neural Network. Jumlah neuron pada hidden layer yang cocok digunakan untuk prediksi bandwidth diperoleh melalui proses percobaan dengan melakukan beberapa kali training. Sebagai acuan awal learning rate yang digunakan adalah 0.01 dan 0.02. Target error adalah 0,001 dengan epoch maksimal sebanyak 1.000.000 dimana proses akan berhenti apabila nilai fungsi kinerja kurang dari atau sama dengan target error yang telah ditentukan atau telah mencapai nilai maksimum epoch.

Tabel 3. Parameter pengujian jumlah neuron dengan target error 0.001

\begin{tabular}{|l|c|l|}
\hline \multicolumn{1}{|c|}{ Parameter } & Nilai & Keterangan \\
\hline Target error (MSE) & 0,001 & Target proses berhenti \\
\hline Learning rate & 0,1 & Kecepatan pembelajaran sistem \\
\hline Jumlah Hidden & $3,5,7,10,15,20,25,30$ & Jumlah lapisan tersembunyi \\
\hline Maksimum epoch & 100.000 & Jumlah iterasi \\
\hline Transfer Function & Sigmoid Binner \\
\hline Bobot & Random $(0,1)$ \\
\hline
\end{tabular}


Hasil percobaan yang didapat dengan menggunakan jumlah neuron yang berbeda-beda pada hidden layer, hasil yang didapat menunjukkan bahwa dengan jumlah neuron sebanyak tigabelas unit menghasilkan nilai error (MSE) terkecil dari seluruh percobaan yaitu sebesar 0.003725 . Proses berikutnya adalah menguji hasil training dengan menggunakan jumlah neuron yang berbeda-beda pada tiap-tiap percobaan.

\subsection{Analisis hasil training dengan windows size}

Proses training yang dilakukan dengan menggunakan parameter windows zise menunjukkan bahwa dengan jumlah node input 8 menghasilkan nilai MSE terkecil yaitu 0.003277. Berdasarkan Tabel 3 dibuatlah grafik perbandingan antara jumlah neuron input terhadap nilai MSE seperti pada Gambar 2.

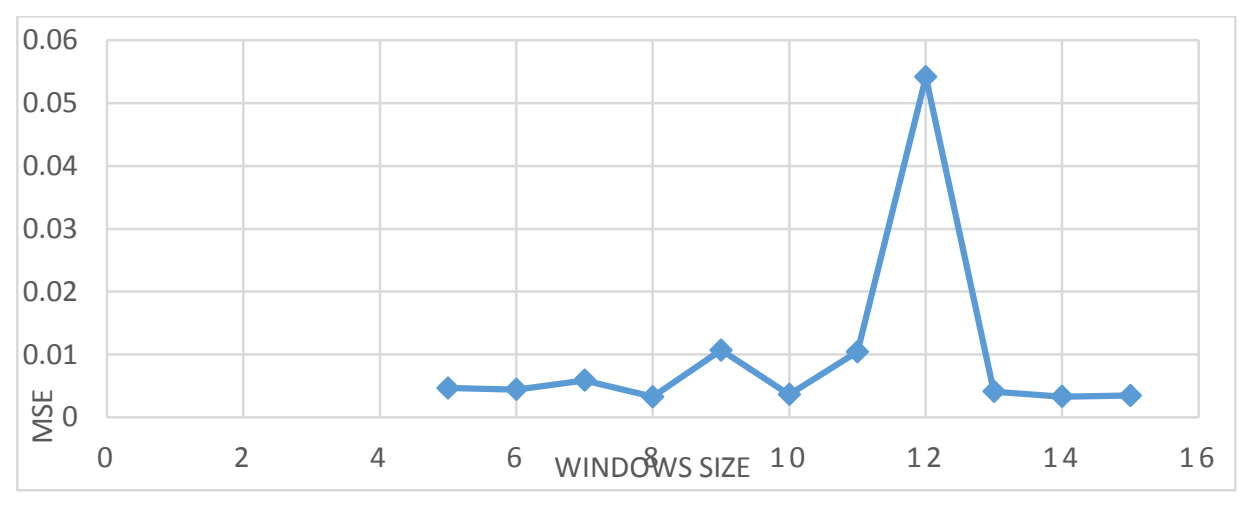

Gambar 2. Grafik perbandingan windows size dan nilai MSE (target 0.001)

Pada saat training dengan target 0.001 nilai epoch maksimum yang ditetapkan adalah 100.000 nilai MSE mengalami peningkatan pada saat jumlah neuron input 12 yaitu 0.054172 .

\subsection{Training dengan jumlah hidden layer}

Pengujian dengan menggunakan parameter jumlah hidden Layer dengan parameter yang ditunjukkan pada Tabel 2. Berdasarkan Tabel 2 dibuatlah grafik perbandingan antara jumlah windows size terhadap nilai MSE seperti pada Gambar 3.

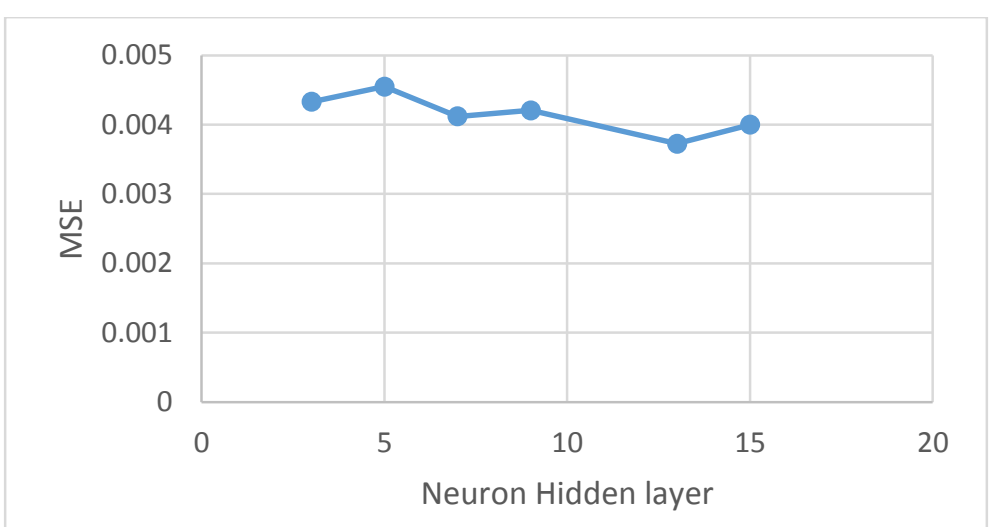

Gambar 3. Grafik perbandingan neuron hidden layer dan nilai MSE (target 0.001)

Pada saat training dengan learning rate 0.01 diperoleh konfigurasi terbaik dengan nilai MSE terkecil yaitu pada jumlah neuron hidden layer 13 yaitu sebesar 0.003725 .

\subsection{Analisis Hasil Testing}

Pada penelitian ini data testing yang digunakan sebesar $20 \%$ dari total data yang digunakan, sehingga jumlah data yang digunakan sebanyak 15 vektor data. Data yang digunakan untuk testing merupakan data 
baru yang tidak diikutsertakan dalam proses training. Tingkat akurasi hasil proses testing sangat dipengaruhi oleh bobot hasil training, yang menunjukkan kemampuan jaringan dalam mengenali pola-pola yang dilatih. Berdasarkan hasil percobaan yang dilakukan, dengan target toleransi error sebesar 0.001 dengan nilai masing-masing parameter sama dengan nilai yang terdapat pada proses training untuk jumlah neuron hidden layer.

Hasil testing dengan jumlah data sebanyak 15 data menghasilkan nilai MSE yang berbeda seperti yang ditunjukkan pada Tabel 4. Berdasarkan hasil testing diperoleh nilai MSE terkecil yaitu pada jumlah neuron hidden layer 13 yaitu sebesar 0.002422 .

\section{Tabel 4. Hasil testing dengan target error 0.001}

\begin{tabular}{|c|c|}
\hline Neuron Hidden & MSE \\
\hline 3 & 0.002513 \\
\hline 5 & 0.002510 \\
\hline 7 & 0.002526 \\
\hline 9 & 0.002625 \\
\hline 13 & 0.002422 \\
\hline 15 & 0.002813 \\
\hline
\end{tabular}

\section{Kesimpulan}

Berdasarkan hasil penelitian dan pembahasan yang telah dilakukan, maka diperoleh kesimpulan sebagai berikut, sistem yang dikembangkan mampu mengenali pola dan dapat dapat melakukan prediksi dalam hal penggunaan bandwidth dengan menggunakan metode jaringan saraf tiruan elman. Hasil training dengan menggunakan windows zise 8 pada maksimum epoch 100.000 diperoleh nilai MSE terkecil sebesar 0.003277. Hasil training dengan menggunakan windows zise 11 pada maksimum epoch 1.000 .000 diperoleh nilai MSE terkecil sebesar 0.002833. Kemudian hasil training untuk jumlah neuron pada hidden layer diperoleh nilai MSE terkecil yaitu pada jumlah neuron 13 sebesar 0.003725 . Hasil testing dengan menggunakan parameter pada percobaan pada jumlah neuron hidden layer 13 diperoleh nilai MSE terkecil yaitu sebesar 0.002422 .

\section{Daftar Pustaka}

[1] R. R. T. d. I. Muarifah, "Implementasi Mikrotik Sebagai Manajemen Bandwidth .," in IST AKPRIND, Yogyakarta, 2012.

[2] T. L. H. F. Pasila. F, "Elman Neural Network Application With Accelerated Lma Training For East Java-Bali Electrical Load Time Series Data Forecasting," 2009.

[3] I. G. R. a. S. A. Mekongga, "The Prediction of Bandwidth On Need Computer Network Through Artificial Neural network Method of Backpropagation," vol. 02, p. 98-107., 2012.

[4] M. S. S. A. R. Aziz, "Enhancement of Particle Swarm Optimization in Elman Recurrent Network with bounded Vmax Function," 2009.

[5] Y. Noorviani, "Penerapan Elman Recurrent Neural network untuk Diagnosis Ganguan Autis Pada Anak," Tesis, Universitas Gadjah Mada Yogyakarta, 2011.

[6] O. Abdalla, "A comparison of feed-forward back-propagation and radial basis artificial neural networks," A Monte Carlo study. In Proceedings 2010 International Symposium on Information Technology - Engineering Technology, p. 994-998, 2010. 